\title{
Identifying trees most likely to die after a partial cut in sugar maple or yellow birch stands
}

\author{
by François Guillemette ${ }^{1 *}$
}

\begin{abstract}
Many research findings related to tree mortality have been published since 2005, and it is now possible to assess postselection cut tree mortality risks in maple or softwood/yellow birch forest stands. This paper sets out some simple, practical criteria that can be used to identify the trees most likely to die, for inventory and tree marking purposes prior to partial cutting. Crown dieback and low quality of the butt log are the two main indications that a sugar maple (Acer saccharum Marshall) is at high risk of mortality. As for yellow birch (Betula alleghaniensis Britton), the presence of a major defect in the trunk or crown dieback are the two main indications of a high risk of mortality. The mortality risk of the other companion species of these stands generally increases with their diameter.
\end{abstract}

Key Words: Mortality, partial cut, tree defect, classification, sugar maple

\section{RÉSUMÉ}

De nombreux résultats de recherche ont été publiés depuis 2005 et permettent maintenant d'évaluer le risque de mortalité des arbres après coupe de jardinage dans une érablière ou une bétulaie jaune à résineux. Cet article propose des critères simples et pratiques pour identifier les arbres les plus susceptibles de mourir, aux fins de l'inventaire et du martelage en préparation d'une coupe partielle. Le dépérissement du houppier et la faible qualité de la bille de pied sont les deux principales indications qu'un érable à sucre (Acer saccharum Marshall) présente un risque élevé de mortalité. Quant au bouleau jaune (Betula alleghaniensis Britton), la présence d'un défaut majeur au tronc ou d'un dépérissement du houppier sont les deux principales indications d'un risque élevé de mortalité. Le risque de mortalité des autres essences compagnes de ces peuplements augmente généralement avec leur diamètre.

Mots Cles : Mortalité, coupe partielle, défaut, classification, érable à sucre

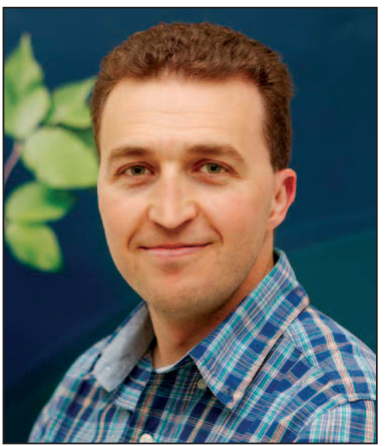

François Guillemette

\section{Introduction}

The silvicultural approaches generally used for unevenaged stands dominated by hardwoods such as sugar maple (Acer saccharum Marsh.) and yellow birch (Betula alleghaniensis Britt.) mostly involve partial cuts, such as selection cutting and regular or irregular shelterwood systems (e.g. OMNR 1998; MRN 2013). A major issue with this type of cut is the need to minimize residual tree mortality in the decades following the harvest. Monitoring of operational selection cuts in Québec's public forests has shown that the net stand increment can be fairly low in the first few years if tree mortality is too high (Bédard and Brassard 2002).
To assess mortality risk, tens of thousands of trees are measured periodically in experimental study sites and in the network used to monitor the real impacts of selection cutting in Québec. A number of findings on tree mortality risks over periods ranging from five to 15 years after selection cutting have been published since 2005 (Majcen et al. 2005; Fortin et al. 2008; Guillemette et al. 2008, 2015, 2017). They provide information that can be used to identify the trees that are most likely to die after selection cuts. The aim of this paper is to present a coherent, practical summary of this information that can serve to select trees for partial cuts in maple or yellow birch forests. The published findings present different mortality probabilities depending on the characteristics of the trees and sites of interest, whereas this paper proposes a single mortality rate threshold above which it is preferable to harvest a given category of trees with similar characteristics (species, diameter, defects), instead of leaving them to grow in preparation for a partial cutting.

\footnotetext{
${ }^{1}$ Researcher in hardwood silviculture, Direction de la recherche forestière, Ministère des Forêts, de la Faune et des Parcs, 2700 Einstein, Québec, P.Q.

G1P 38W; * e-mail : francois.guillemette@mffp.gouv.qc.ca
} 


\section{Critical mortality rate}

I did not find any reference in the scientific literature to identify critical mortality rates in preparation of a partial cut. I first considered comparing the mortality rate of each category of trees to the annual basal area increment rate. It seems obvious that if the mortality rate for a category of trees is equal to or higher than its basal area increment rate, then no gain would be achieved by allowing the trees to grow. However, in practice, this idea would generate one major problem, since for sugar maple, this situation was limited to trees with broken roots or those that had lost a large percentage of their crown. I consulted our data from 34 plots of 0.25 ha in the Sainte-Véronique forest $\left(46.60^{\prime} \mathrm{N}, 74.95^{\prime} \mathrm{W}\right)$ and found that the proportion of basal area meeting this criterion was $2.6 \%$ for sugar maple (2075 trees) and $14.7 \%$ for yellow birch (466 trees). This proportion of $2.6 \%$ for maple seemed to be too low to be useful in silviculture, given that the harvest rate of partial cuts is generally 25 to $40 \%$ and that we know that losses by mortality can reach $8 \%$ of the residual basal area of the stands during the first 5 years following a selection cutting (Bédard and Brassard 2002).

Instead, I suggest that the mortality risk for hardwood trees be considered too high when the probability of mortality is equal to or more than twice the basic mortality rate, i.e., the rate for healthy, good quality trees with a DBH of $40 \mathrm{~cm}$ (DBH: diameter at breast height, measured 1.3 metres above the ground). This basic rate per 25 -year period is $5.4 \%$ for sugar maple and $10.3 \%$ for yellow birch (or 0.2 and $0.4 \%$ per year; Guillemette et al. 2008). It was decided to present mortality rates calculated on a 25 -year basis rather than an annual basis because this better reflects the cutting cycle. The choice of $40 \mathrm{~cm}$ as the benchmark $\mathrm{DBH}$ to calculate the mortality rates is based on the fact that this value is close to the median $\mathrm{DBH}$ for which accurate tree selection is required in a partial cutting; harvesting is recommended when a tree's DBH is over $45 \mathrm{~cm}$, i.e., when it reaches financial maturity (Guillemette 2016). On sites located in the warmest, driest region of the province of Québec (near the border with Ontario), this $45 \mathrm{~cm} \mathrm{DBH}$ threshold is also associated with a high risk of windthrow difficult to detect beforehand (Guillemette et al. 2017), meaning that identification of trees most likely to die based on their defects becomes less critical. In addition, hardwood trees with a DBH of less than $34 \mathrm{~cm}$ generally do not contain high-value factory sawlogs (Havreljuk et al. 2015) or higher grade boards (Bédard et al. 2018), meaning that they are of less interest for harvesting. Consequently, trees with a DBH of roughly $40 \mathrm{~cm}$ need more attention in order to minimize post-partial cut lumber losses. Finally, the application of this minimum threshold of double the basic mortality rates to the dataset previously mentioned results in a proportion of the basal area of 24.9 and $16.2 \%$ for sugar maple and yellow birch, respectively. Thus, this threshold would cover a good proportion of the expected harvest, which is usually 25 to $40 \%$ of the basal area, while leaving room for other considerations.

\section{Sugar maple and yellow birch trees most likely to die}

This section describes the trees most likely to die, based on the mortality rates published in Guillemette et al. (2008, 2015) and the minimum threshold of double the basic mor- tality rate for each species, i.e., roughly $11 \%$ per 25 years for sugar maple and $21 \%$ per 25 years for yellow birch. I propose to apply the recommendations developed for sugar maple to red maple (Acer rubrum L.), since no better information specific to this latter species is available. Fortin et al. (2008) have considered the mortality risk for red maple in sugar maple stands, and they showed that it is similar to the risk for sugar maple trees.

In view of the foregoing, the sugar maple and yellow birch trees most likely to die are:

1) Partially uprooted sugar maple and yellow birch trees or trees whose roots have been cut by machinery (25-year mortality rate of 79 to $100 \%$, Guillemette et al. 2008).

2) Sugar maple trees with no sawlog potential. Their 25 -year mortality rate is at least $16.1 \%$ (Guillemette et al. 2008) and increases quickly if the tree exhibits one of the defects listed in Table 1 (e.g., 25.3\% where fungus is present).

3) Sugar maple trees with sawlog potential but also exhibiting a major bole defect and dieback or breakage affecting more than $10 \%$ of the crown (Table 1 ).

4) Sugar maple trees and yellow birch trees with good-quality, relatively defect-free boles, but with dieback or breakage affecting more than $25 \%$ of the crown (25-year mortality rate of at least $12.6 \%$ for sugar maple and $25.5 \%$ for yellow birch).

5) Yellow birch trees with major bole defects (Table 1).

The mortality risk is below the proposed threshold for sugar maple trees with sawlog potential if there is little to no sign of crown dieback, and this, even if major bole defects are visible (Table 1 ).

It is important to note that the minimum recommended quality threshold when assessing the sawlog potential of standing hardwood trees is Grade C (MRN 1995). The grading system used in Québec is an adaptation of the American system (Hanks 1976), which also forms the basis of the proposed Nova Scotia system (Calvert and Petro 1993). Briefly, in Grade C, on the second-worst face (of the four bole faces) of the best $3.7 \mathrm{~m}$ grading section of the tree (the first $5.0 \mathrm{~m}$ ), there must be at least $1.8 \mathrm{~m}$ of clear-face bole cutting potential (defect-free), which may be subdivided into sections of no less than $60 \mathrm{~cm}$ in length. In addition, the volume reduction for rot, crook and sweep must be no more than $50 \%$ of the volume of the assessed log. Trees that do not meet the Grade C minimum criteria are Grade $\mathrm{D}$, that is, trees with no sawlog potential, hence rather destined for pulp.

\section{Other species in hardwood forests}

Other species exhibit high 25-year mortality rates after partial cuts in maple or yellow birch forests. They include shadeintolerant hardwoods (mortality of $\geq 62.4 \%$; Guillemette et al. 2017), such as white birch (Betula papyrifera Marsh.) and aspens (Populus spp.), regardless of their DBH and even for trees of good quality. Prévost and Dumais (2013) also reported very high mortality rates of paper birch in two yellow birch - conifer stands. The 25-year mortality rate of American beech (Fagus grandifolia Ehrh.) is likely to be very high when the stand is in one of the first two phases of beech bark disease (advancing front and killing front phases, Houston 1994). Subsequently, in the aftermath forest phase, some trees will be weakened but other, more resistant trees will 
Table 1. Major bole defects and examples of 25 -year mortality rates for a tree with a DBH of $40 \mathrm{~cm}$ growing in moderate conditions according to Guillemette et al. (2008). The definitions used in the mortality risk studies have been adjusted to those in Boulet's (2005) MSCR classification. N.A., not available. Values shown in boldface are roughly double the basic mortality rate, or higher.

\begin{tabular}{|c|c|c|c|c|c|}
\hline \multirow[b]{4}{*}{ Major defect } & \multirow[b]{4}{*}{ Brief description } & \multicolumn{4}{|c|}{ 25-year mortality risk (\%) } \\
\hline & & \multicolumn{3}{|c|}{ Sugar maple with sawlog potential } & \multirow[b]{3}{*}{ Yellow birch } \\
\hline & & \multicolumn{3}{|c|}{ Percentage of crown dieback } & \\
\hline & & $0 \%$ & $11 \%$ & $26 \%$ & \\
\hline Decay & $\begin{array}{l}\text { Symptoms of deep rot visible in injuries } \\
\text { (all origins), cracks or nots where the hole } \\
\text { is at least } 10 \mathrm{~cm} \text { in diameter. }\end{array}$ & 7.0 & 10.1 & 16.1 & N. A. ${ }^{\dagger}$ \\
\hline Fungus & $\begin{array}{l}\text { Presence of a sporophore, stroma or false } \\
\text { basidiocarp (code SP). }\end{array}$ & 8.6 & 12.5 & 19.8 & 46.5 \\
\hline Canker & Presence of cambium necrosis (code NC). & 8.6 & 12.5 & 19.8 & 46.5 \\
\hline Wound $>1$ face & $\begin{array}{l}\text { Exposure of sapwood, by mechanical or } \\
\text { animal means, over a width of more than } \\
25 \% \text { of the bole's circumference. }\end{array}$ & 8.4 & 12.4 & 19.2 & 19.5 \\
\hline $\begin{array}{l}\text { Wound caused } \\
\text { by a bird or insect }\end{array}$ & $\begin{array}{l}\text { Exposure of sapwood due to the action of } \\
\text { a sugar maple borer or woodpecker (hole). }\end{array}$ & 7.6 & 11.0 & 17.4 & N. A. \\
\hline None & & 5.4 & 7.9 & 12.6 & 10.3 \\
\hline
\end{tabular}

${ }^{\dagger}$ Even if decay was not a variable in the analysis model for yellow birch, I suspect that it nevertheless has an impact that can be assessed indirectly because it is often associated with lack of lumber potential or presence of a wound. These two variables significantly increase the mortality risk.

begin to emerge. The mortality rate among this latter group is likely to be similar to the rate observed prior to the onset of the disease. In this case, the mortality rate increases quickly with $\mathrm{DBH}$, achieving double the base rate at a $\mathrm{DBH}$ of roughly $35 \mathrm{~cm}$ (mortality $\geq 19.5 \%$ at a $\mathrm{DBH}>35 \mathrm{~cm}$; Guillemette et al. 2008, 2017).

There have been few in-depth studies of softwood mortality risk after partial cuts in hardwood-dominated stands. However, the findings of Fortin et al. (2008) suggest that the 25-year mortality rate for balsam fir (Abies balsamea [L.] Mill.) in sugar maple stands is $66.3 \%$ at a DBH of $15 \mathrm{~cm}$ and increases quickly with $\mathrm{DBH}$. Very high rates of fir mortality have also been reported after partial cutting in yellow birch conifer stands (Prévost and Dumais 2013; Raymond et al. 2016). It is important to note that these high mortality rates were observed between two outbreaks of spruce budworm (Choristoneura fumiferana Clemens). So, I recommend determining which firs are most likely to die solely on the basis of their DBH. In the network used to monitor the real impacts of selection cutting (see Guillemette et al. 2017), the mortality rate for spruce (Picea spp.), observed over 10 years and converted to a 25 -year base, was $65.6 \%$ starting with a $\mathrm{DBH}$ of $24 \mathrm{~cm}$ (unpublished data, 338 uninjured trees including 85 with a DBH of at least $24 \mathrm{~cm}$ ). However, this mortality was observed mainly in the western portion of the province of Québec, i.e., in the Outaouais and Témiscamingue regions. In two other sectors located in the surroundings of Québec City, Prévost and Dumais (2013) observed averaged mortality rates of 8.1 and $13.5 \%$ over 10 years (22 and $37 \%$ over 25 years) for red spruce (Picea rubens Sarg.) after partial cutting for any DBH. In another nearby area, Raymond et al. (2016) observed a mortality rate in red spruce of approximately $1 \%$ per five-year period (5.1\% over 25 years) following partial cutting. However, spruce with defects, such as split, bole injury, partial rupture, or lean $\left(>30^{\circ}\right)$, have more than tripled the basic spruce mortality. After a partial cut followed by an intense site preparation in a fourth sector of said surroundings, Prévost and Charrette (2018) reported a post-partial cut 10 -year mortality rate of $67 \%$ (or $100 \%$ over 25 years) for white spruce (Picea glauca [Moench] Voss) at an average DBH of $38 \mathrm{~cm}$.

Therefore, for most of these sugar maple and yellow birch companion species with high early mortality rates, I recommend deciding which trees are most likely to die based solely on the combination of DBH and species (Table 2). This method offers the advantage of not requiring species to be graded during pre-harvest inventories for silvicultural prescriptions, thereby saving money. In some situations, the choice of the minimum DBH for harvesting may be influenced by how easy it is to sell a given species. However, my recommendation for spruce is to apply a $\mathrm{DBH}$ threshold of $24 \mathrm{~cm}$ only in one of these three locations: in the western part of the province of Québec, on a site very exposed to winds (see Waldron et al. 2013) or in a stand with intense site disturbance expected after logging. Otherwise, the assessment of mortality risks could be done based on the presence of bole defects. 
Implications for forest management in Québec

These findings and recommendations have variable implications depending on the silvicultural treatments and local methods used to select the trees that will be kept or harvested during partial cuts. In Québec, the MSCR harvest priority classification system (Boulet 2005) was introduced in 2005 to improve harvesting of less vigorous trees following preselection cut marking. Although the priority class for harvesting is denoted by the letter " $M$ ", which refers to the risk that the tree will die (mourir in French) before the next harvest, the system appears to give more weight to the risk of bole degradation than to tree vigour (Moreau et al. 2018). The information sources used to develop this system were focused more on the risk of bole decay than on empirical data on mortality rates by defect. This explains why the system focuses on the presence of tree rot indicators. Conversely, the recommendations I make here are solely based on observed mortality rates, which have led me to place more emphasis on the presence of crown dieback and butt log quality instead of rot indicators, especially for sugar maple. A study published in the United States in 2015 also revealed the importance of crown dieback signs when assessing sugar maple's mortality risks (Morin et al. 2015). However, that particular study did not use this criterion in conjunction with major bole defects. With more detailed data, emphasis can be placed on the cumulative effects of different major defects, including crown dieback. This does not mean that trees classified as M in the MSCR system do not have a high mortality rate; on the contrary, this rate is estimated at $85.3 \%$ over 25 years (Guillemette et al. 2015). However, other than for the obvious situation of windthrow or trees broken below the crown, it is difficult to identify trees with a high mortality risk based on a single defect in the MSCR classification system. For example, some trees classified as "R" (reserved for future use) exhibit high mortality rates ( $31.7 \%$ over 25 years) even though dieback affects only a small percentage of the crown (11 to 25\%; Guillemette et al. 2015).

In managing trees based on mortality risk, greater priority should be given to signs of crown dieback and butt log quality. In addition, to simplify the assessment task and reduce partial cut preparation costs, the classification process can be limited to high-value species, usually sugar maple and yellow birch, occasionally the spruce too (see Table 2). The risk to most other species could well be managed by establishing a single DBH threshold per species. In addition, other elements must also be considered in preparation for diagnosis and silvicultural prescriptions, including stand structure, present and future tree quality (value) and the impacts of partial cutting on residual tree growth and regeneration (Guillemette et al. 2013).

Lastly, a warning is in order. These recommendations do not apply to situations in which a natural disturbance has damaged crowns across the entire stand (e.g., an ice storm or insect infestation). The guidelines presented here are likely to be too severe in situations such as these (see Shortle et al. 2014).

\section{Conclusion}

This summary of knowledge offers a simple, effective way of assessing mortality risk in preparation for diagnosis and silvicultural prescriptions in hardwood-dominated stands. The financial savings that could be achieved using this method should be evaluated, as well as the performance benefits of silvicultural prescriptions derived from it.

\section{Acknowledgements}

I would like to thank Steve Bédard and David Pothier for their useful comments on a preliminary version of this text, Denise Tousignant for linguistic revision of the first French version, and Christine Gardner for the English translation. I would also like to thank the Associate Editor, an anonymous reviewer and Philippe Nolet for their very good comments that helped improve the final version of this text. My thanks also go to Patricia Raymond and Hugues Power for the spruce mortality risk assessment. Finally, I would also like to thank Simon Bilodeau-Gauthier for the revision of the final versions in French and English. 


\section{References}

Bédard, S. and F. Brassard. 2002. Les effets réels des coupes de jardinage dans les forêts publiques du Québec en 1995 et en 1996. Ministère des Ressources naturelles, Charlesbourg (Qc). 15 p. http://collections.banq.qc.ca/ark:/52327/bs44736.

Bédard, S., I. Duchesne, F. Guillemette and J. DeBlois. 2018. Predicting volume distributions of hardwood sawn products by tree grade in eastern Canada. Forestry: An International Journal of Forest Research 91(3): 341-353. https://doi.org/10.1093/forestry/cpx043. Boulet, B. 2005. Défauts externes et indices de la carie des arbres: guide d'interprétation. Les Publications du Québec, Québec (Qc). $291 \mathrm{p}$.

Calvert, W.W. and F.J. Petro. 1993. Grading standing hardwood trees in Nova Scotia. W.W. Calvert \& Associates, Margaree (NS). 71 p. Fortin, M., S. Bédard, J. DeBlois and S. Meunier. 2008. Predicting individual tree mortality in northern hardwood stands under uneven-aged management in southern Québec, Canada. Ann. For. Sci. 65: 205. https://doi.org/10.1051/forest:2007088.

Guillemette, F. 2016. Diamètres à maturité pour l'érable à sucre et le bouleau jaune au Québec. Gouvernement du Québec, Ministère des Forêts, de la Faune et des Parcs, Direction de la recherche forestière. Note de recherche forestière $n^{\circ} 145.14$ p. http://www.mffp. gouv.qc.ca/publications/forets/connaissances/recherche/Guillemett e-Francois/Note145.pdf

Guillemette, F., S. Bédard and M. Fortin. 2008. Evaluation of a tree classification system in relation to mortality risk in Québec northern hardwoods. For. Chron. 84(6): 886-899. https://doi.org/10.5558/ tfc84886-6

Guillemette, F., S. Bédard, D. Pin and D. Dumais. 2013. Chapitre 23 - Les coupes de jardinage avec gestion par arbres, in Ministère des Ressources naturelles (édit.), Le guide sylvicole du Québec, Tome 2 - Les concepts et l'application de la sylviculture, collective work under the supervision of C. Larouche, F. Guillemette, P. Raymond and J.-P. Saucier, Les Publications du Québec, Québec (Qc). 566-603.

Guillemette, F., S. Bédard and F. Havreljuk. 2015. Probabilités de mortalité des feuillus selon le classement de la priorité de récolte. Gouvernement du Québec, ministère des Forêts, de la Faune et des Parcs, Direction de la recherche forestière. Avis technique $n^{\circ}$ SSRF-5. 11 p. http://www.mffp.gouv.qc.ca/publications/forets/connaissances/ recherche/Guillemette-Francois/Avis-technique-SSRF-5.pdf.

Guillemette, F., M.-M. Gauthier and R. Ouimet. 2017. Partitioning risks of tree mortality by modes of death in managed and unmanaged northern hardwoods and mixedwoods. For. Chron. 93(3): 246-258. https://doi.org/10.5558/tfc2017-033.

Hanks, L.F. 1976. Hardwood tree grades for factory lumber. USDA Forest Service, Research Paper NE-333. 81 p. https://www.fs. usda.gov/treesearch/pubs/3946.

Havreljuk, F., S. Bédard, F. Guillemette and J. DeBlois. 2015. Predicting log grade volumes in northern hardwood stands in southern Quebec. Proceedings of the $5^{\text {th }}$ International Scientific Conference on Hardwood Processing (ISCHP2015), Sept. 15-17, Québec (Qc). 107-114.
Houston, D.R. 1994. Major new tree disease epidemics: Beech bark disease. Ann. Rev. Phytopathol. 32: 75-87. https://doi.org/10.1146/ annurev.py.32.090194.000451.

Majcen, Z., S. Bédard and S. Meunier. 2005. Accroissement et mortalité quinze ans après la coupe de jardinage dans quatorze érablières du Québec méridional. Gouvernement du Québec, Ministère des Ressources naturelles, Direction de la recherche forestière. Mémoire de recherche forestière $\mathrm{n}^{\circ} 148.39$ p. https://mffp. gouv.qc.ca/publications/forets/connaissances/recherche/BedardSteve/Memoire148.pdf

Moreau, E., S. Bédard, G. Moreau and D. Pothier. 2018. Relationships between tree vigor indices and a tree classification system based upon apparent stem defects in northern hardwood stands. Forests 9: 588. https://doi.org/10.3390/f9100588.

Morin, R.S., K.C. Randolph and J. Steinman. 2015. Mortality rates associated with crown health for eastern forest tree species. Environ. Monit. Assess. 187(3): 87. https://doi.org/10.1007/s10661-015-4332-x. MRN (Ministère des Ressources naturelles). 1995. Classification des tiges d'essences feuillues. Normes techniques. Gouvernement du Québec, Ministère des Ressources naturelles, Service des inventaires forestiers. $73 \mathrm{p}$.

MRN (Ministère des Ressources naturelles). 2013. Le guide sylvicole du Québec, Tome 2. Les concepts et l'application de la sylviculture, collective work under the supervision of C. Larouche, F. Guillemette, P. Raymond and J.-P. Saucier, Les Publications du Québec, Québec (Qc). 744 p.

OMNR (Ontario Ministry of Natural Resources). 1998. A silvicultural guide for the tolerant hardwood forest in Ontario. Ontario Ministry of Natural Resources. Queen's Printer for Ontario. Toronto, ON. 500 p. http://www.ontla.on.ca/library/repository/ mon/8000/223116.pdf.

Prévost, M. and D. Dumais. 2013. Decennial growth and mortality following uniform partial cutting in yellow birch - conifer stands. Can. J. For. Res. 43: 224-233. https://dx.doi.org/10.1139/cjfr-20120440

Prévost, M. and L. Charrette. 2018. Rehabilitation silviculture in a high graded temperate mixedwood stand in Quebec, Canada. New Forests. https://doi.org/10.1007/s11056-018-9690-0.

Raymond, P., M. Prévost and H. Power. 2016. Patch Cutting in Temperate Mixedwood Stands: What Happens in the BetweenPatch Matrix? For. Sci. 62(2): 227-236. https://dx.doi.org/10.5849/ forsci.15-023

Shortle, W.C., K.T. Smith and K.R. Dudzik. 2014. Tree survival 15 years after the ice storm of January 1998. USDA Forest Service, Northern Research Station, Research Paper NRS-25. Newtown Square (PA). 4 p. https://www.nrs.fs.fed.us/pubs/45483.

Waldron, K., J.-C. Ruel and S. Gauthier. 2013. The effects of site characteristics on the landscape-level windthrow regime in the North Shore region of Quebec, Canada. Forestry 86: 159-171. 